UNITEU STATES DEPARTMENT OF THE INTERIOR GEOLOGICAL SURVEY

\title{
RESULTS OF INSTRUMENTAL NEUTRUN ACTIVATION ANALYSES \\ FOR SELECTED PLUTONIC SAMPLES FROM THE \\ SALINIAN BLOCK, CALIFORNIA COAST RANGES
}

by

Donald C. Ross

OPEN-FILE REPORT

$82-935$

This report is preliminary and

has not been edited or reviewed

for conformity with Geological

Survey standards and nomenclature.

Menlo Park, California

1982 


\section{LIST OF ILLUSTRATIONS}

Figures

1. Location of samples

2. Modal plot of selected samples of plutonic rocks of the Salinian block.

3. REE abundances relative to chondrites, showing individual data points for selected samples of plutonic rocks of the Salinian block.

4. Gadolinium (Gd) values as reported by laboratory compared with 40 percent reduction suggested because of standardization problems.

5. REE abundances relative to chondrites, selected plutonic suites of the Salinian block.

6. REE patterns of representative central Sierra Nevada granitoids (modified slightly from Dodge and others, 1982).

7. REE abundance relative to chondrite for selected granitic rocks of the southernmost Sierra Nevada (Ross, in press).

8. Value of Eu/Eu* plotted against $\mathrm{SiO}_{2}$ for selected plutonic rocks of the southernmost Sierra Nevada and for the Salinian block.

Tables

1. Instrumental neutron activation analyses, Salinian block, California (in ppm).

2. Modes of instrumental neutron activation analyzed specimens. 
for selected plutonic samples from the

Salinian block, California Coast Ranges

In 1977, samples of 12 plutonic rocks from the Salinian block (Fig. 1) and two samples from unusual gabbroic rocks along the San Andreas fault (588, Logan; and 130, Gold Hill) were analyzed for trace elements, including some of the rare earth elements (REE), by neutron activation techniques (Table 1). For some inexplicable reason the results of these analyses were buried and temporarily lost in my files. They were only resurrected in May 1982 during a house cleaning of Salinian block material and these results have therefore never appeared in any of my Salinian block reports. The belated release of these data at this time with a short description and several figures will finally make them available for use in comparisons with other plutonic terranes along the Pacific continental margin and elsewhere.

The 12 samples from the Salinian block were selected from previously chemically analyzed rocks that ranged geographically from Bodega Head south to the La Panza Range (Fig. 1) and compositionally through the range from quartz diorite to granite (Table 2, Fig. 2) (Ross, 1972). Quartz diorite and tonalite were probably oversampled considering the areal distribution of granitic rock types in the Salinian block and this should be kept in mind in making any sweeping comparison with other granitic sites. Likewise, 12 samples from this rather vast granitic terrane is hardly an adequate sample, but I think that all the major rock types and most of the larger plutonic units have been touched and, with discretion, these data can be considered somewhat representative of the granitic terrane of the Salinian block.

Samples were also analyzed from the unusual hornblende quartz gabbro (Logan, 588, Table 1) and the anorthositic gabbro (Gold Hill, 139, Table 1) 
that are not part of the Salinian block, but are present along its eastern boundary (the San Andreas fault). Data on these gabbroic rocks (Ross, 1970) are included here as their presence must be taken into account in models of Salinian block reconstruction.

Table 1 shows the analytical results for 23 trace elements, but it is the rare earth elements, the last ten of the table from lanthanum (La) to lutetium (Lu), that will be emphasized in the following discussion. A standard plot of the abundances of the various REE for each plutonic rock relative to the REE abundance in average chondrite is shown on Figure 3 . It is worth noting at this point that the gadolinium (Gd) values shown for 5 samples on Table 1 are suspect and the analyst suggests that they may be 40 percent high due to standardization problems. For the plots of Figure 3 the Gd values have been reduced 40 percent from the value shown on Table 1. Figure 4 shows a portion of the "chondrite plot" with both the reported and reduced Gd values. It is apparent from this plot that the analytically reported Gd value enhances the Eu anomaly of those 5 samples, but also gives the chondrite plot a pronounced Gd spike. In any case, the plots of Figure 3 and discussions of the Eu anomaly have some degree of uncertainty because of the Gd problem.

A quick survey of the plots of Figure 3 shows that the gabbros of Gold Hill and Logan and the charnockitic tonalite of the Santa Lucia Range (lower left plot) are all relatively flat and "primitive." The anorthositic gabbro of Gold Hill (139) has a particularly unusual pattern with a positive Eu anomaly. The other 3 sets of plots of Figure 3 are from the typical plutonic suite of the Salinian block (tonalite, granodiorite, and granite) and have normal differentiated patterns.

Perhaps the most striking feature of Figure 3 is that only three samples show pronounced Eu anomalies--the granites from the Ben Lomond area (496) and Point Reyes (518) and, somewhat surprising to me, the charnockitic tonalite of the Santa Lucia Range (2283). Another surprise is that the granite from the 
Gabilan Range (546) has a very small Eu anomaly for a felsic rock with 75 percent $\mathrm{SiO}_{2}$. Figure 5 lumps the tonalites in one group and the granodiorites and granites in another and somewhat rounds off the rough edges of the Figure 3 plots. These Figure 5 plots emphasize the minor Eu anomalies for most samples. The lack of a significant Eu anomaly for the granite from the Gabilan Range (546) sharply contrasts to the pronounced anlmalies for 496 and 518. A similar lack of an Eu anomaly, where one was expected, was noted in a granite from the Tejon Lookout area of the Sierra Nevada tail (Figure 7). That sample with an $\mathrm{SiO}_{2}$ percentage of 75.5 , had a slight positive Eu anomaly, in contrast to two samples from the same unit that had Eu anomalies about as strong as 496 of Figure 5. Also, one sample each in the granodiorites of Claraville and Gato-Montes in the southernmost Sierra Nevada (Fig. 7, see arrows) lacks an Eu anomaly in units where other samples show a marked Eu anomaly. The significance that can be attached to these differences is uncertain, considering the limited data. F. C. W. Dodge (written commun., 1982) believes these Eu anomaly contrasts, which reflect differences in feldspar fractionation, are highly significant and point toward differing processes of formation for separate parts of what appears to be the same intrusive unit. Could this be a correlative character? Note, for example, that Dodge and others (1982) report that the leucogranites have a pronounced and consistent Eu anomaly in a representative suite of granitic rocks from the central Sierra Nevada, but granodirites and plagioclase-rich granitoids show virtually no Eu anomalies (Fig. 6).

The lack of pronounced Eu anomalies for most samples from the Salinian block (Figs. 3 and 5 ) suggests a possibly significant contrast with the readily apparent Eu anomalies for most of the 35 samples analyzed from the southernmost Sierra Nevada (Fig. 7). To give a more quantitative basis for the apparent visual contrast between the Salinian block and southernmost Sierra samples, I plotted the Eu/Eu* ratio against $\mathrm{SiO}_{2}$ percentage for all 
the 12 Salinian block samples and added all the similarly plotted points from the southerninost Sierra Nevada. The plot (Figure 8) shows less contrast than the visual comparison suggested. Perhaps a steeper gradient from samarium $(\mathrm{Sm})$ to europium (Eu) in some of the Salinian block samples relative to the Sierra samples accounts for some of the Salinian block Eu anomaly. There is, moreover, a pronounced gadolinium (Gd) "nump" in a number of southernmost Sierra Nevada samples. Perhaps the Gd values of Table 1 are closer to real values than I have shown by reducing them $40 \%$ on Figures 3 and 5 . Gadolinium determinations have probably achieved greater accuracy between 1977 (when the Salinian block rocks were analyzed) and the later determination of the southernmost Sierra Nevada rocks, judging by the fact that Gd is reported for almost all the southernmost Sierra Nevada samples (and in amounts lower than 2 ppm). Perhaps the "difference" between the Salinian block and southernmost Sierra Nevada REE patterns is an artifact of improved technique? Except for the "visual contrast" in Eu anomalies, the overall REE trends of Figure 5 are closely comparable to those of the southernmost Sierra Nevada. 
Dodge, F. C. W., Millard, H. T., J., and Elsheimer, H. N., 1982, Compositional variations and abundances of selected elements in granitoid rocks and constituent minerals, central Sierra Nevada batholith, California: U.S. Geological Survey Professional Paper 1248, 24 p.

Ross, D. C., 1970, Quartz gabbro and anorthositic gabbro--markers of offset along the San Andreas fault in the California Coast Ranges: Geological Society of America Bulletin, v. 81, p. 3645-3662.

- 1972 Petrographic and chemical reconnaissance study of some granitic and gneissic rocks near the San Andreas fault from Bodega Head to Cajon Pass, California: U.S. Geological Survey Professional Paper 698, $92 \mathrm{p.}$ - (in press), The metamorphic and plutonic rocks of the southernmost Sierra Nevada, California and their tectonic framework: U.S. Geological Survey Professional Paper _____ 


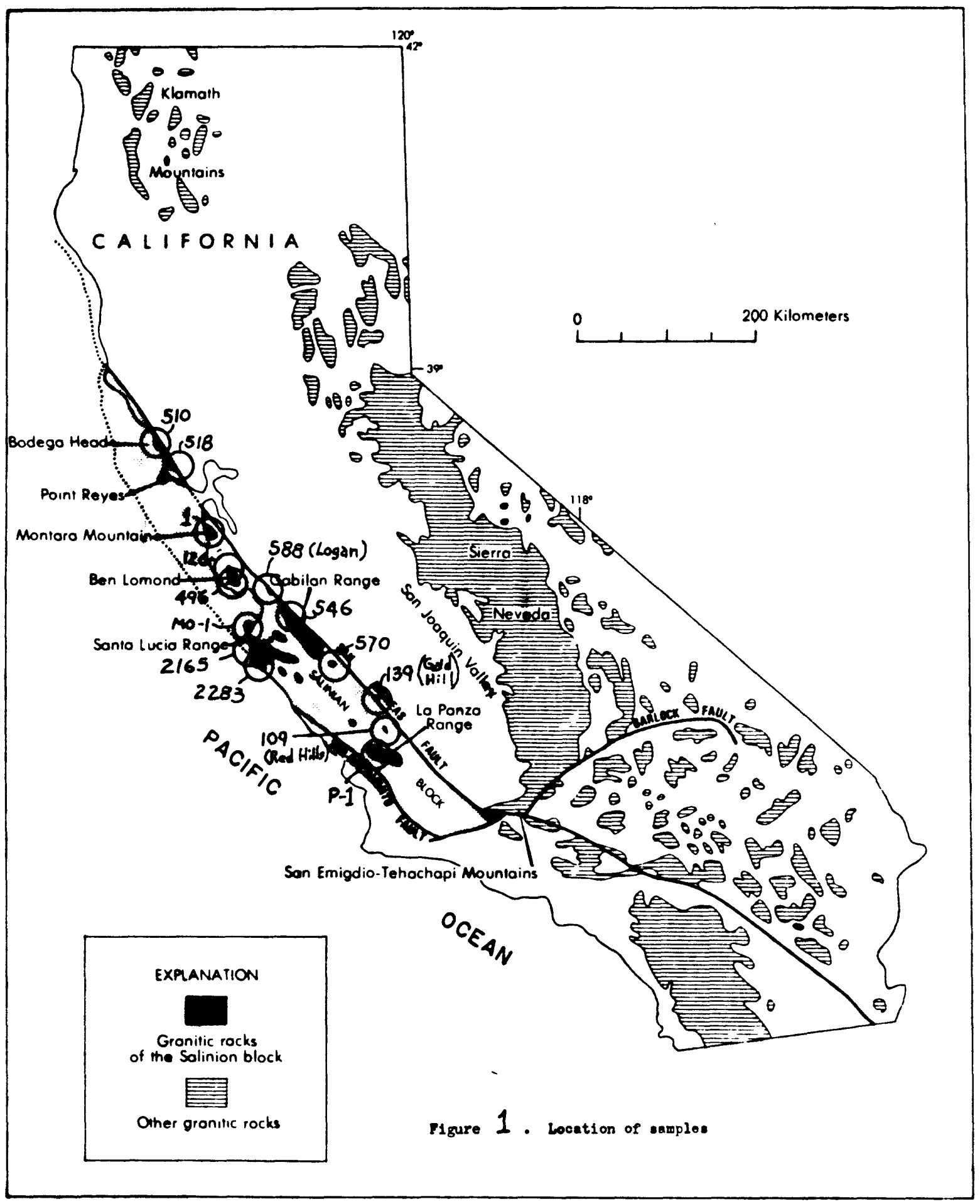




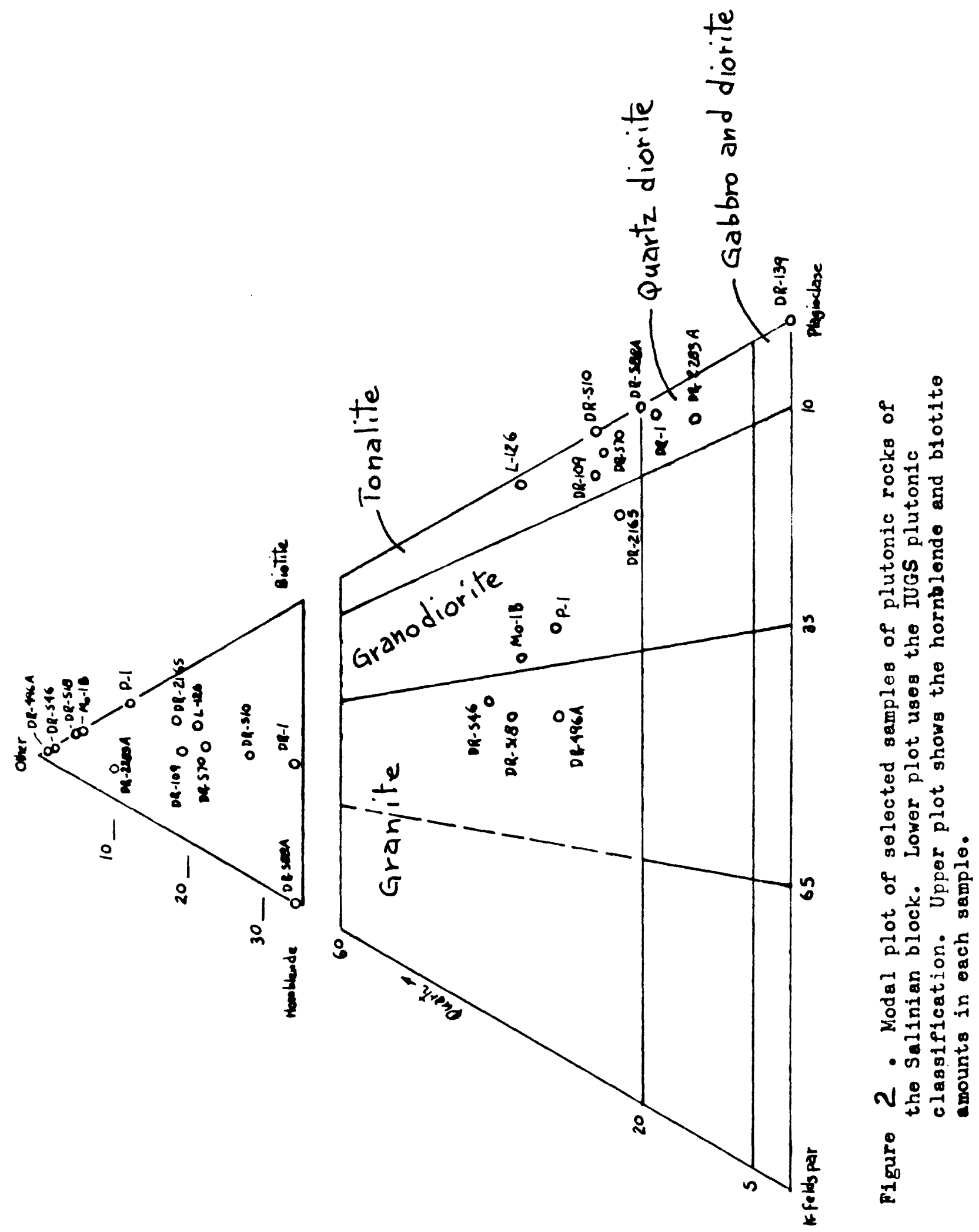



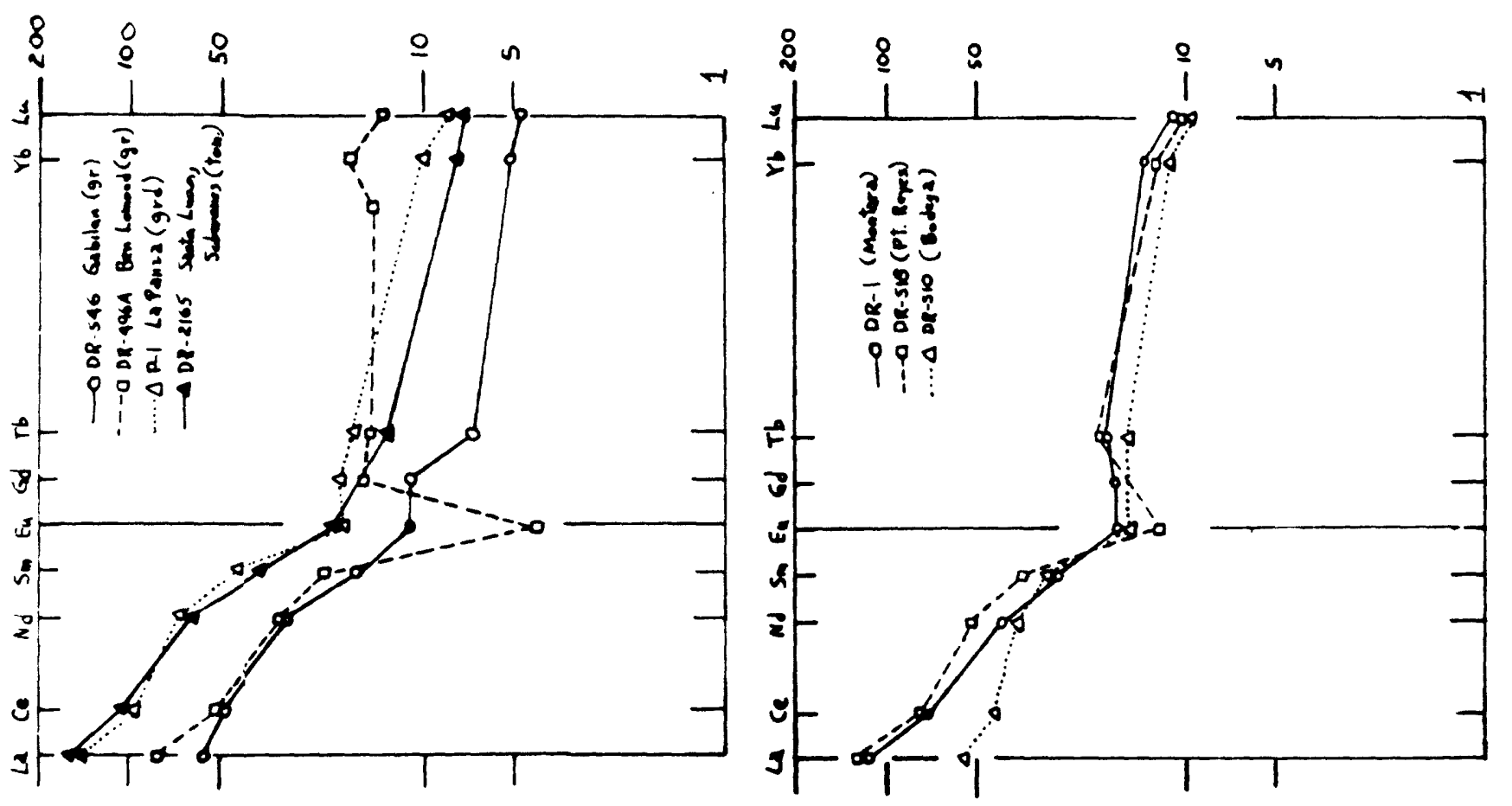

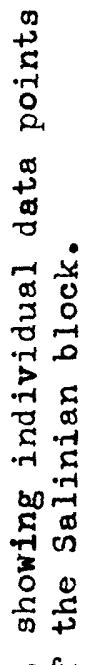

का पू

$+$
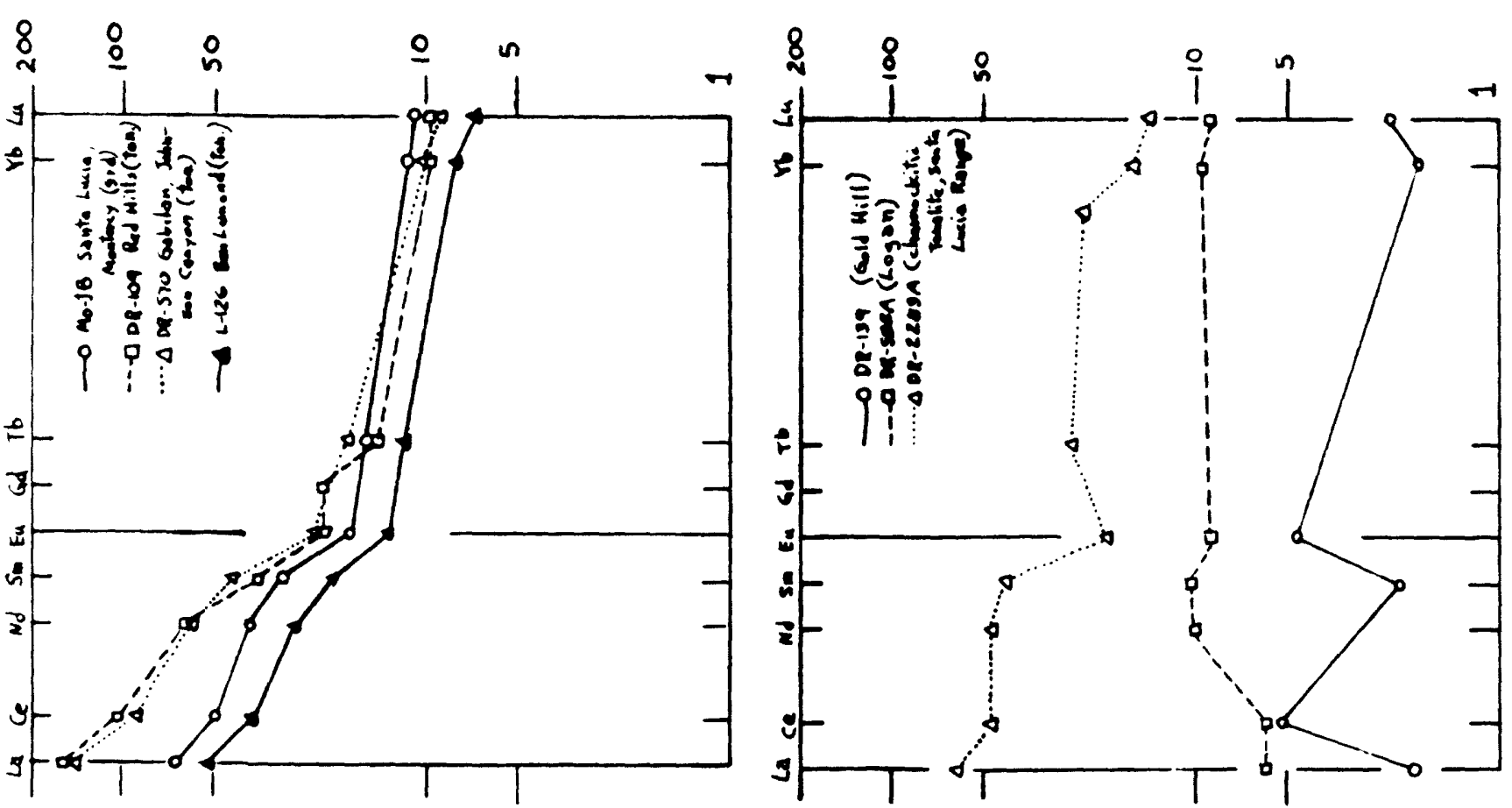

资

돌

웅

$\stackrel{5}{2}$

सै

क

\&

ำ

อ ซ

ช

के

经易

도

m

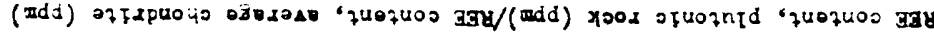




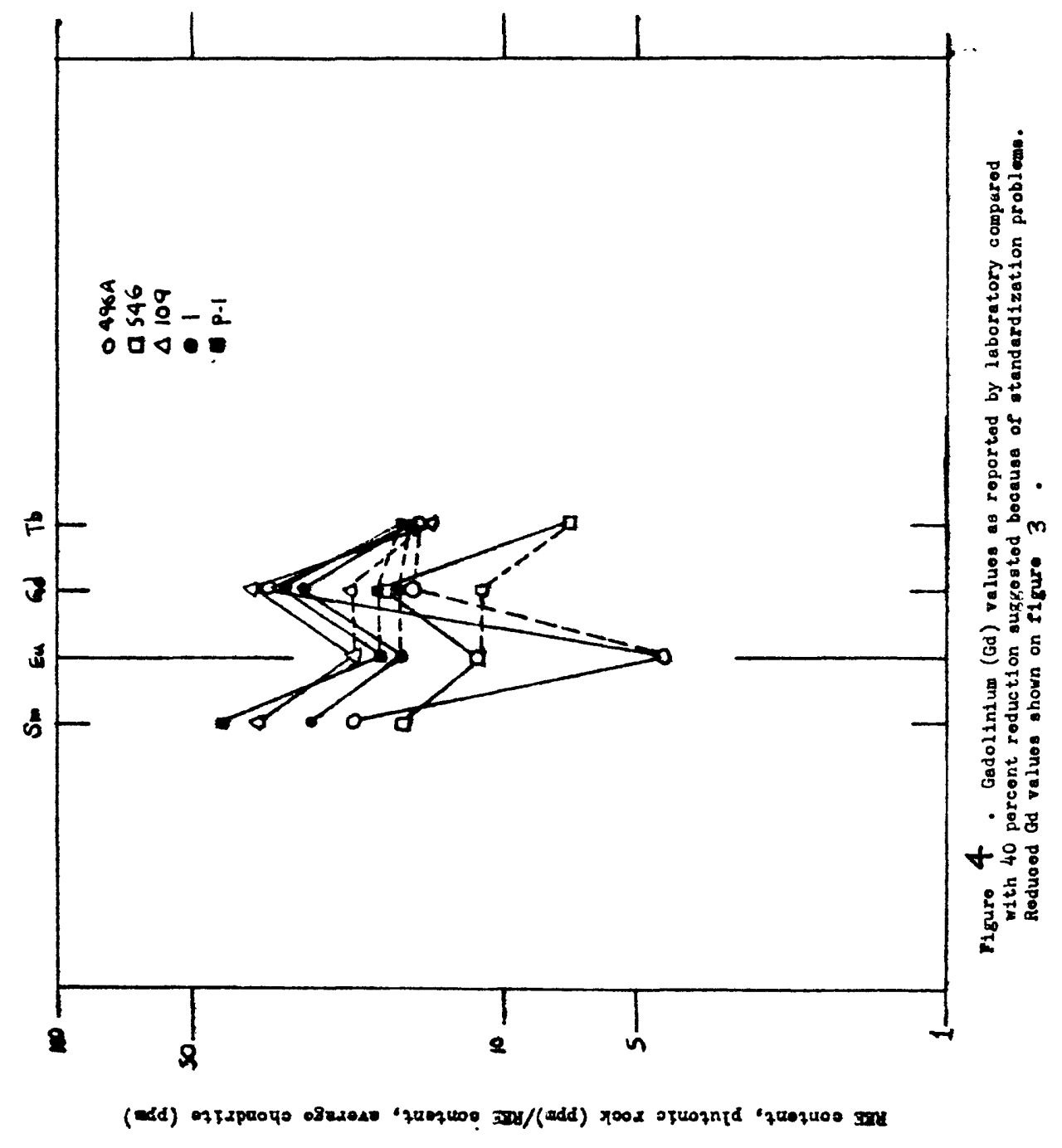




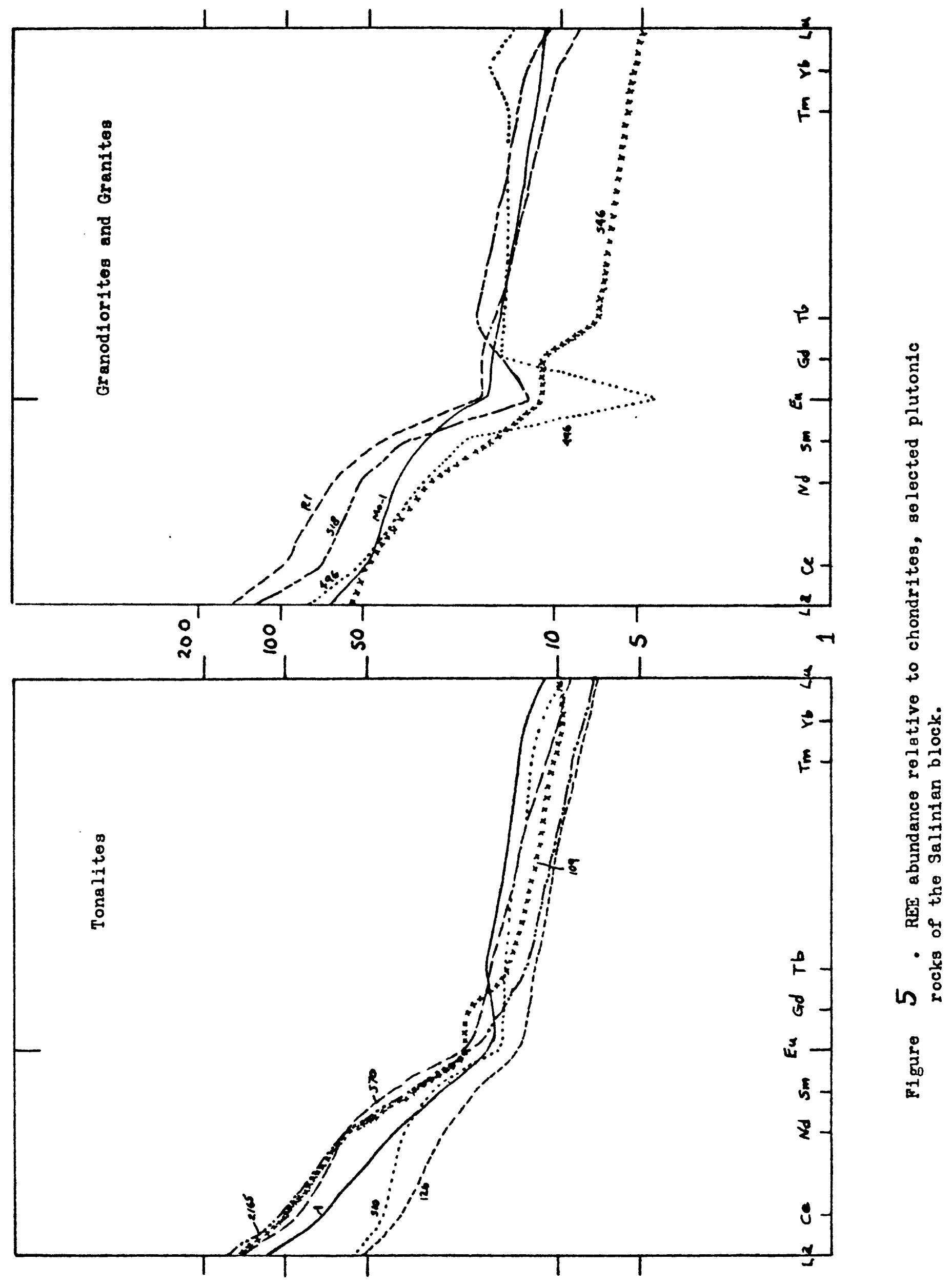

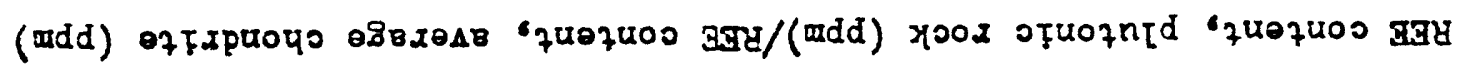



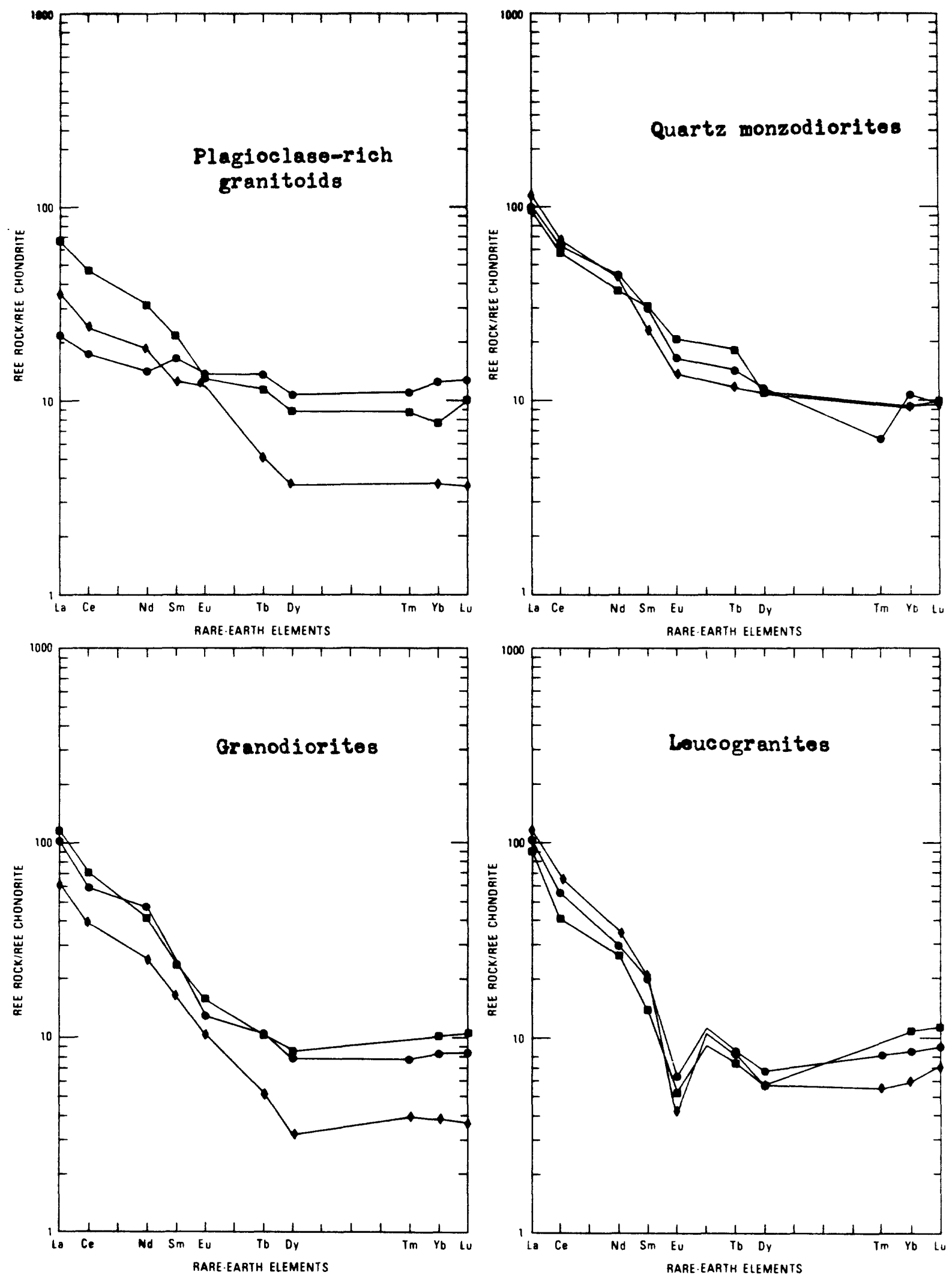

representative

Figure 6. REE patterns of central Sierra Nevada granitoids (modified slightly from Dodge and others, 1982). 


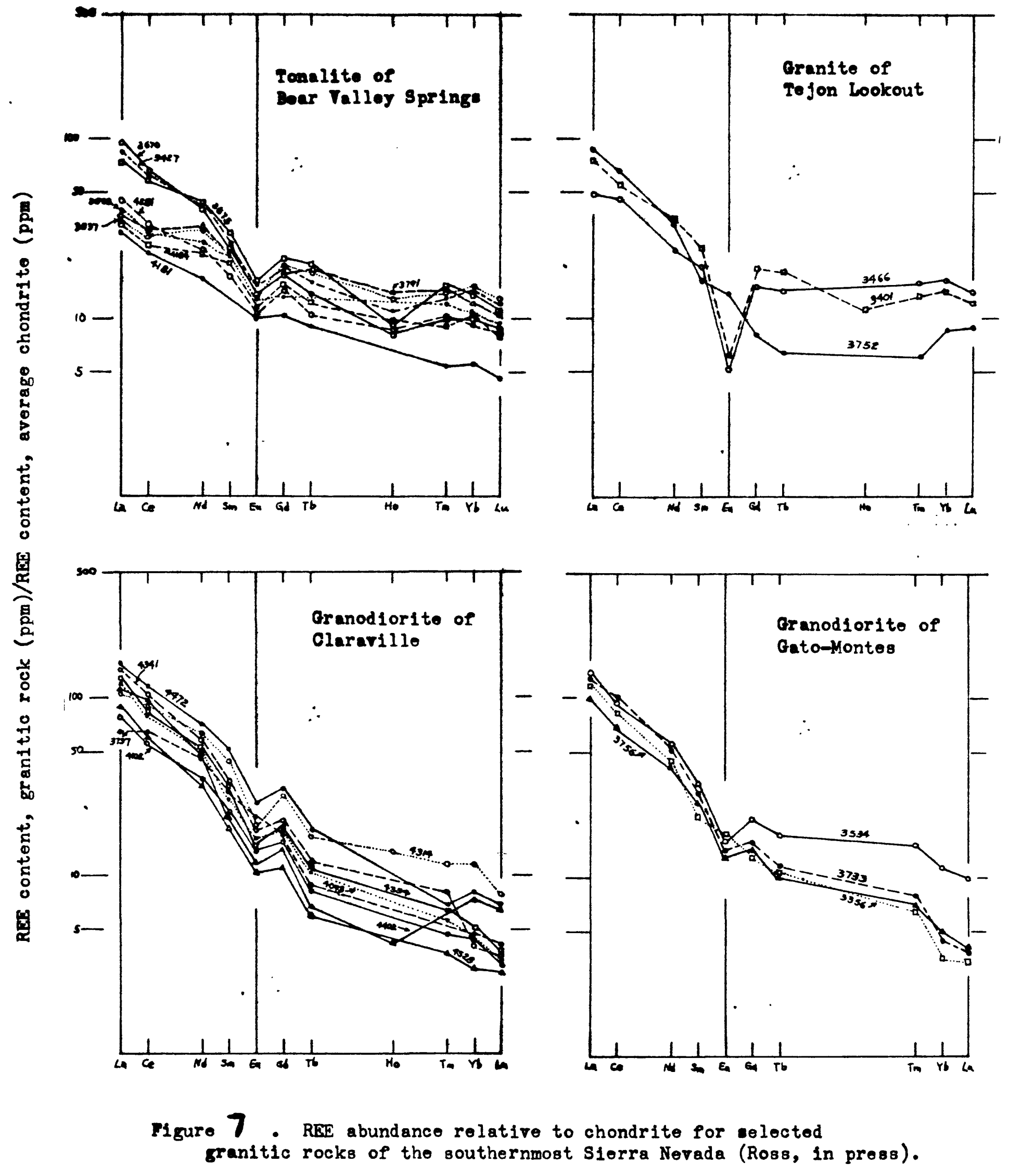




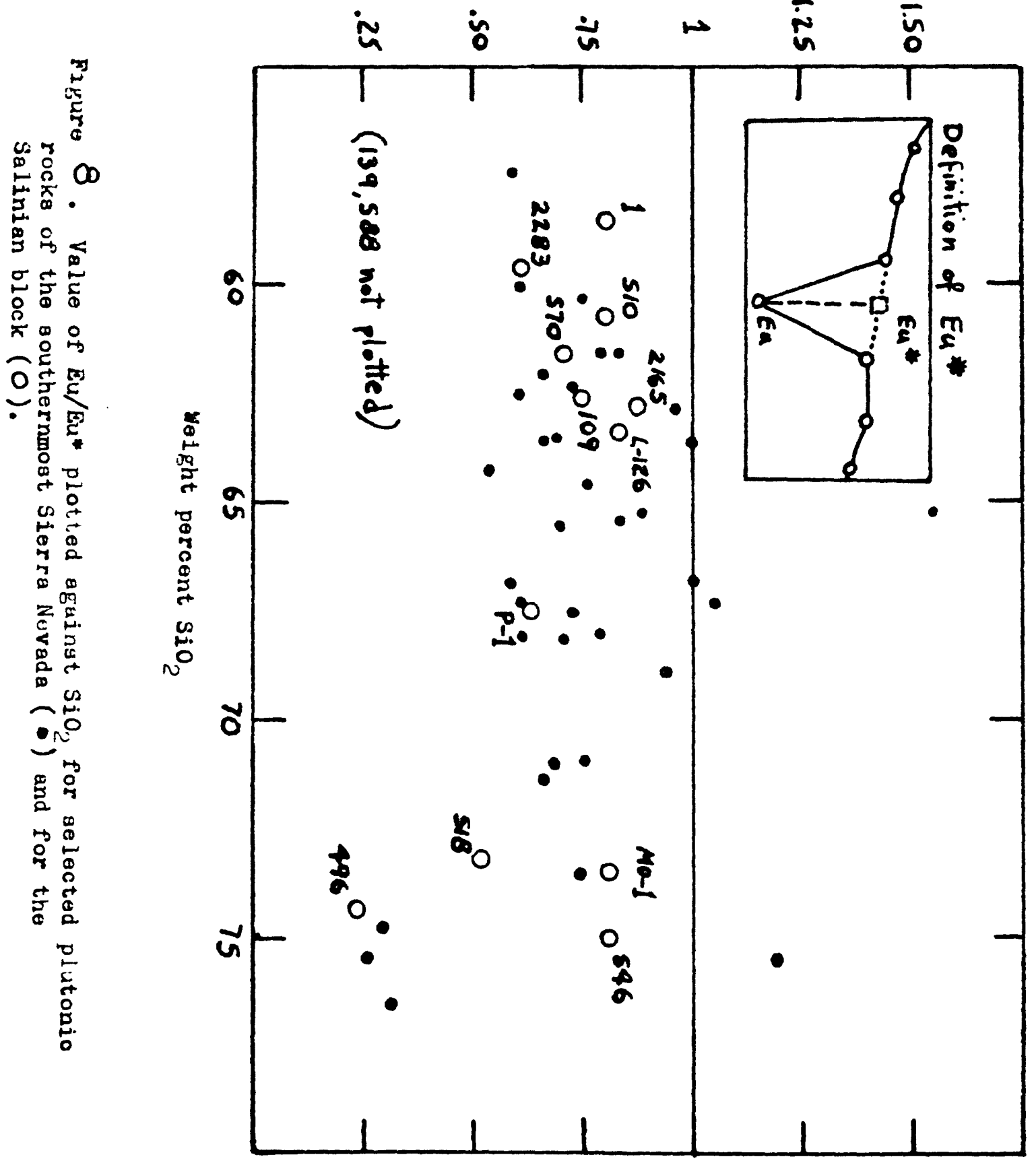




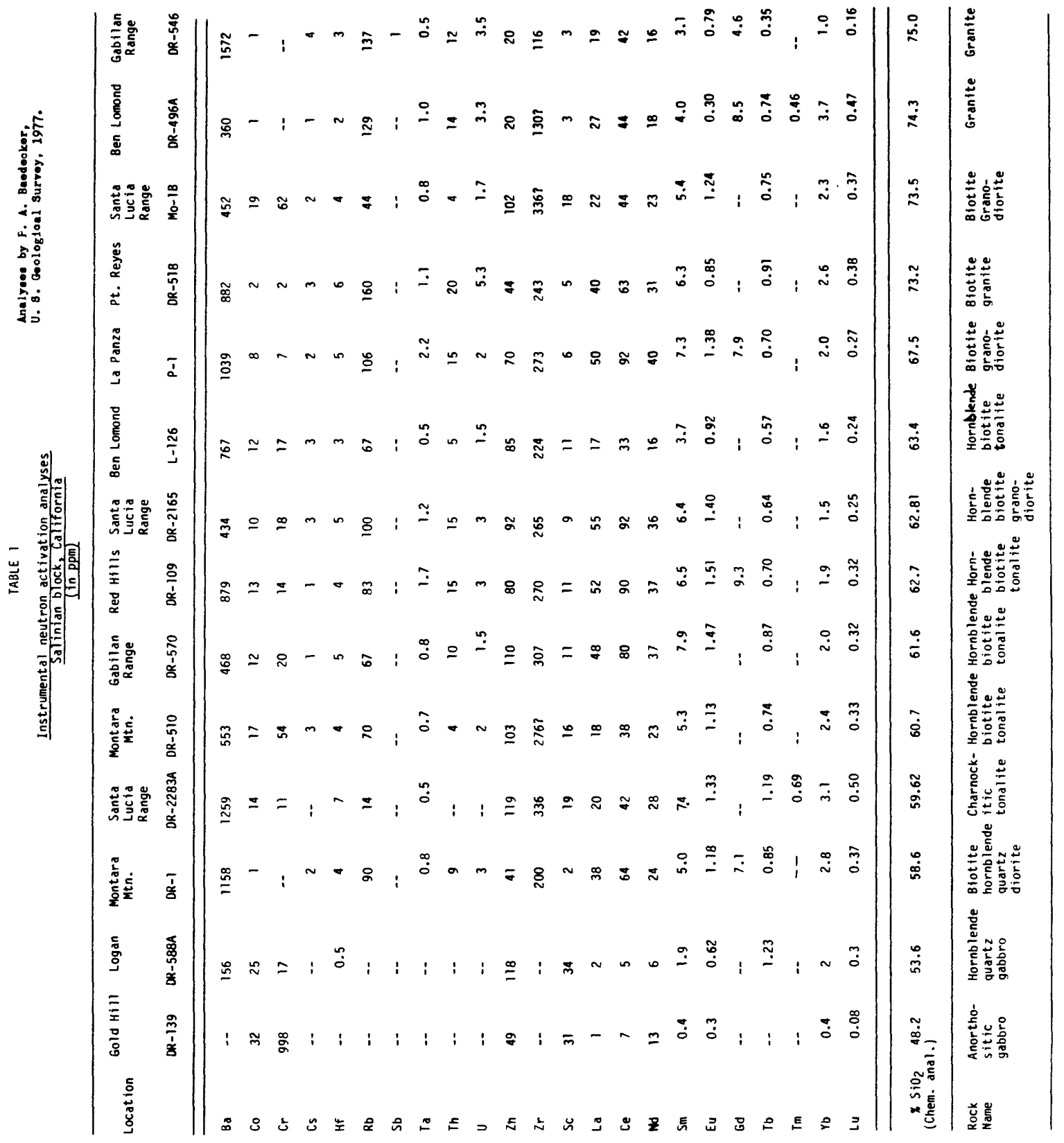




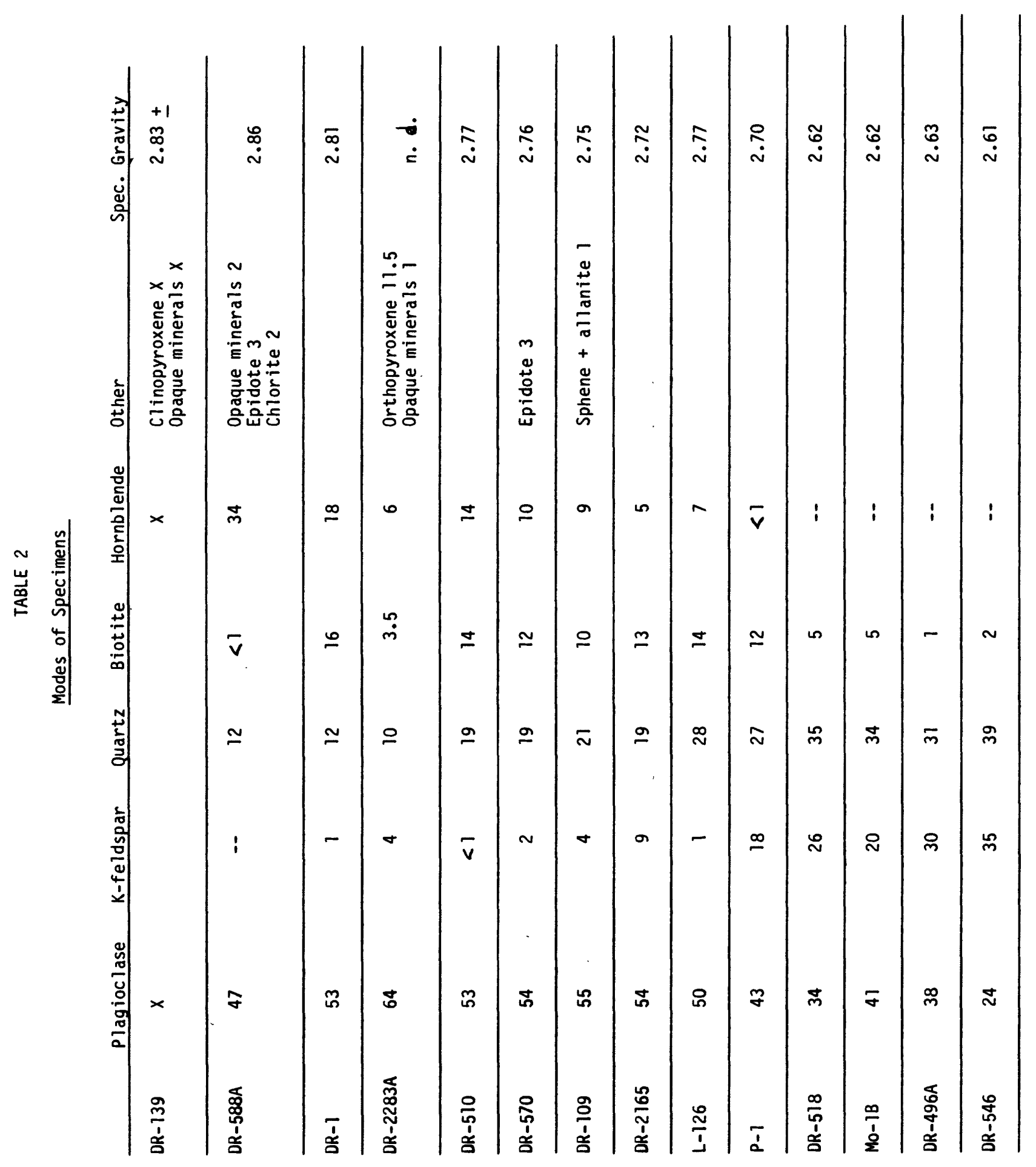

